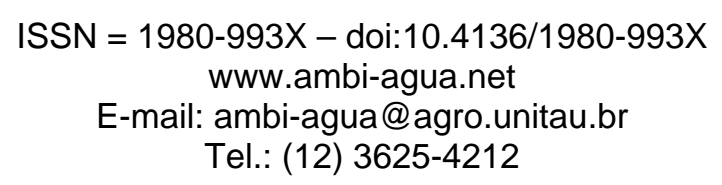

\title{
Caracterização dos parâmetros de qualidade da água do manancial Utinga, Belém, PA, Brasil
}

(http://dx.doi.org/10.4136/ambi-agua.202)

\author{
Vanilda de Magalhães Martins Vasconcelos ${ }^{1}$; Claudinei Fonseca Souza ${ }^{2}$ \\ ${ }^{1}$ Universidade de Taubaté - UNITAU \\ e-mail: picelos@yahoo.com.br \\ ${ }^{2}$ Universidade Federal de São Carlos - UFSCAR \\ e-mail: cfsouza@cca.ufscar.br
}

\section{RESUMO}

Este estudo centrou-se na caracterização de alguns parâmetros físicos, químicos e biológicos da qualidade da água do Manancial do Utinga, que compreende as águas do rio Guamá, Lago Água Preta e Lago Bolonha, localizado no Complexo Hídrico Estadual do Utinga. A área de estudo compreendeu os Lagos Água Preta e Bolonha, que têm nascentes naturais, porém $90 \%$ da água desses lagos são captadas do rio Guamá, levadas para o Lago Água Preta através de uma adutora para o Lago Bolonha, onde é captada novamente para a estação de tratamento do Bolonha. Como resultados, os dados mostraram uma relação que envolve o crescimento populacional da área e o aumento da produção de esgoto não tratado lançado nos corpos d’água. E como conseqüência, observaram-se alterações importantes nas variáveis físicas: cor e turbidez; e nas variáveis biológicas: coliformes totais e variáveis química, N-amoniacal e nitratos, quando comparadas com a resolução 357 CONAMA. Os resultados mostraram que a população residente no entorno do manancial do Utinga, nas proximidades do Lago Bolonha, apresenta deficiência de atendimento em relação ao saneamento básico (coleta de lixo e tratamento de esgoto sanitário).

Palavras-chave: manancial urbano, tratamento de água, recursos hídricos, degradação ambiental.

\section{Characterization of water quality parameters of the reservoir Utinga, Belém, PA, Brazil}

\section{ABSTRACT}

This study focused on the characterization of physical, chemical and biological water quality of the Fountain of Utinga, which includes the river Guamá, Água Preta Lake and Bolonha Lake, located in the State Water Complex called Utinga. The study area comprises the Lakes Água Preta and Bolonha that have natural springs, but $90 \%$ of the water of these lakes are up-taken from the river Guamá to the Água Preta Lake and then through a pipeline to Bolonha Lake, where it is treated in the Bolonha station. Results showed a relationship between the increase in population and the production of untreated sewage released into bodies of water, and as a consequence, significant deterioration in physical variables such as: color and turbidity, and in the biological variable coliform and chemical variables including $\mathrm{N}$-ammonia and nitrate as compared with the CONAMA resolution 357 standards. The results showed that the population that lives in the vicinity of the reservoir Utinga nearby Bolonha lacks adequate sanitation systems (garbage collection and sewage treatment).

Keywords: Urban watershed; water treatment; water resources; environmental degradation. 
VASCONCELOS, V. de M. M.; SOUZA, C. F. Caracterização dos parâmetros de qualidade da água do manancial Utinga, Belém, PA, Brasil. Ambi-Agua, Taubaté, v. 6, n. 2, p. 305-324, 2011. (doi:10.4136/ambiagua.202)

\section{INTRODUÇÃO}

A água, que é um dos recursos naturais mais importantes, pois constitui a matéria predominante nos organismos vivos, vem sendo fortemente alterada com as mudanças demográficas, a velocidade e a extensão da globalização e com o desenvolvimento socioeconômico impulsionado pelo avanço tecnológico. Esses fatores têm sido observados como preponderantes para o aumento da demanda sobre os recursos hídricos, refletindo na sua escassez e na deterioração dos mananciais.

É conhecido que dos 3\% de água doce disponíveis no planeta, apenas 0,01\% localiza-se nos rios e nos lençóis freáticos, sendo esse percentual utilizado para o consumo do homem e de outros seres vivos. Dessa forma, a água passou a ser uma preocupação crescente não apenas no que se refere à quantidade disponível, mas, principalmente, em relação à sua qualidade, acarretando prejuízos e restrições nos seus usos múltiplos.

Os problemas relativos à qualidade da água envolvem um espectro bastante amplo dentro das áreas de estudo hidroambiental e na determinação das potenciais fontes de contaminação resultantes de: disposições inadequadas dos resíduos líquidos e sólidos, de natureza doméstica e industrial; alterações provocadas por empreendimentos para geração de energia (barragens); resfriamento de águas de termoelétricas, além das práticas agrícolas e de criação de animais em pequenas áreas nas bacias urbanas. Todas essas ações antropogênicas acarretam impactos que se inter-relacionam com os processos naturais que ocorrem na bacia.

A situação se agrava, em decorrência do efeito acumulativo gerado pelo crescimento populacional desordenado e a falta de planejamento nas cidades têm se tornado uma constante ameaça à saúde da população. Os esgotos são despejados de forma natural nas valas e nos rios, a água contaminada é a causa principal de várias enfermidades. A influência do homem nesse contexto de contaminação de lençóis freáticos, desmatamento, alteração das propriedades físicas, químicas e biológicas do meio ambiente tem levado a uma expressiva queda da qualidade da água e diminuição da biodiversidade aquática.

Nesse sentido, a proposta deste trabalho aborda a medida dos parâmetros de qualidade da água bruta extraída pela Companhia de Saneamento do Pará (COSANPA) no Manancial do Utinga, devido à reclamação da população belenense quanto à qualidade da água que está chegando às torneiras das residências. E para isso a pesquisa buscou responder ao seguinte questionamento: os níveis de $\mathrm{pH}$, cor aparente, turbidez, n- amoniacal, nitrato e coliforme total encontrados nas águas do manancial do Utinga interferem na qualidade da água distribuída pela Cosanpa na cidade de Belém do Pará?

\section{MATERIAL E MÉTODOS}

\subsection{Caracterização da Área de Estudo}

A cidade de Belém situa-se na foz do Amazonas entre as coordenadas $1^{\circ} 27^{\prime} 21^{\prime \prime}$ ' S e $48^{\circ}$ 30' 15' ' W, em média com altitude de 4 m do nível do mar e possui uma área de 2.161.191 $\mathrm{Km}^{2}$ e 2,1 milhões de habitants, com clima tropical em média de $26^{\circ} \mathrm{C}$ ao ano e total pluviométrico variando de 2.225 a 3.300 mm/ano (Pará, 2005b).

A cidade de Belém limita-se ao norte com a baía de Marajó, a leste, com os municípios de Marituba e Ananindeua, a oeste e ao sul, com o rio Guamá (Pará, 1995). Na parte sul da cidade de Belém encontra-se o rio Guamá, que desemboca na baía do Guajará. Na baía também desemboca o rio Acará (Ramos, 2004).

O Parque Ambiental do Utinga tem área de 1.340 ha, localizado dentro da APA na região metropolitana de Belém, no estado do Pará (Figura1), o maior da Amazônia e um dos três 
maiores do Brasil, localizado entre as coordenadas geográficas $1^{\circ} 22^{\prime} \mathrm{S}$ e $48^{\circ} 20^{\prime} \mathrm{W}$ (Pará, 2005a). O lago Bolonha possui uma área de $1,8 \mathrm{Km}^{2}$ formado com o igarapé do Utinga e o lago Água Preta, com uma área de aproximadamente $7,2 \mathrm{Km}^{2}$, que nasce no município de Ananindeua, percorre grande extensão de área habitada desse município, atinge o município de Belém, forma o lago Água Preta e desemboca no rio Guamá (Figura 2). Ambos são abastecidos com água bruta do rio Guamá (Pará, 1995; Teixeira, 2003).

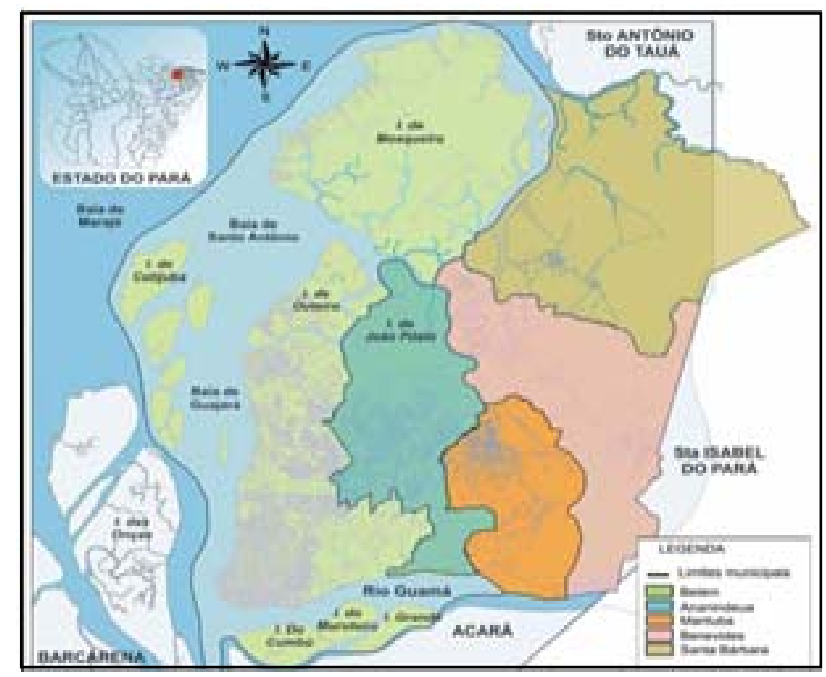

Figura 1. Região Metropolitana de Belém.

Fonte: Companhia de Habitação do Pará (2003).

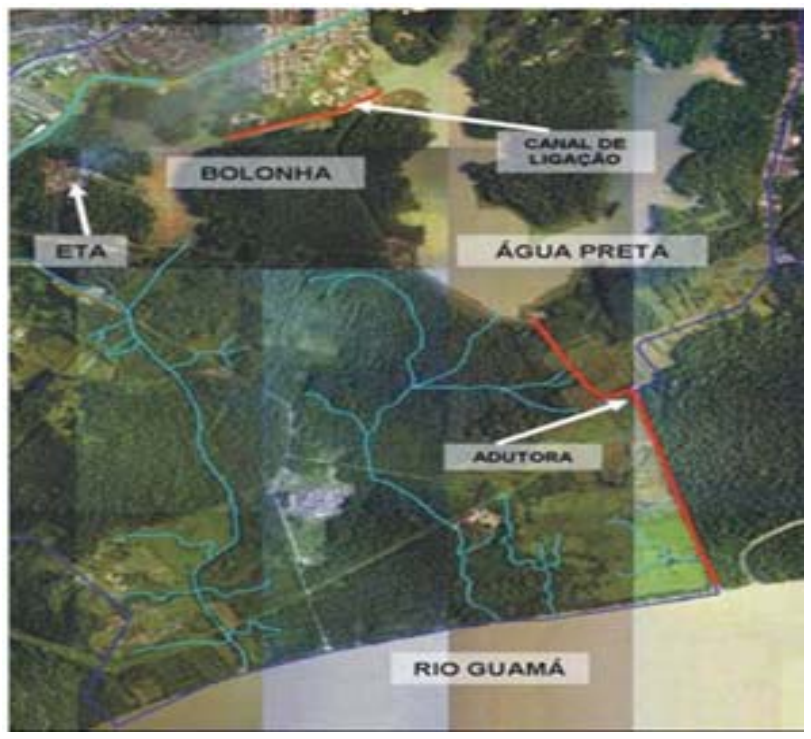

Figura 2. Lagos Bolonha e Água Preta.

Fonte: Adaptado de Google Earth (2010).

\subsection{Caracterização dos dados das amostras}

A avaliação foi realizada por meio da análise e interpretação do monitoramento realizado pela Companhia de Saneamento do Pará (COSANPA) - Unidade Executiva de Controle de Qualidade (UECQ), no período de janeiro de 2007 a setembro de 2009. As coletas foram realizadas em três pontos. O primeiro ponto fica às margens do rio Guamá, na estação de 
VASCONCELOS, V. de M. M.; SOUZA, C. F. Caracterização dos parâmetros de qualidade da água do manancial Utinga, Belém, PA, Brasil. Ambi-Agua, Taubaté, v. 6, n. 2, p. 305-324, 2011. (doi:10.4136/ambiagua.202)

captação, o segundo e o terceiro pontos das amostras foram retirados da parte central dos lagos Água Preta e Bolonha.

Ponto de coleta 1 - localizado na estação de captação, às margens do rio Guamá, coordenadas $1^{\circ} 27^{\prime} 15^{\prime}$ ' S e 4²4'08'’ W (Figura 3).

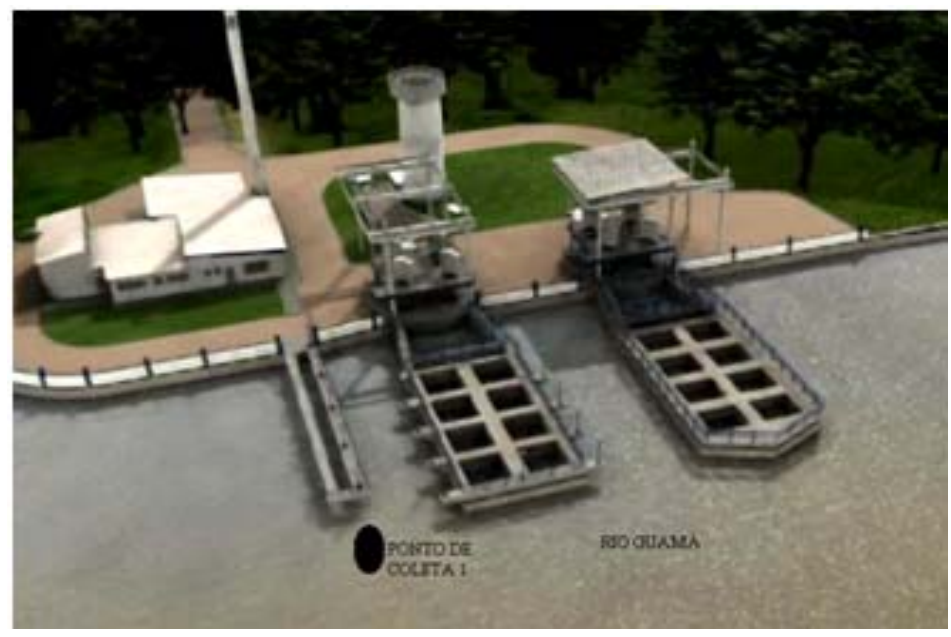

Figura 3. Ponto de coleta 1, rio Guamá.

Ponto de coleta 2 - localizado no lago Água Preta, a amostra foi retirada na parte central, à esquerda do lago, coordenadas $1^{\circ} 25^{\prime} 07.06^{\prime}$ 'S e $48^{\circ} 24^{\prime} 32.83^{\prime \prime} \mathrm{O}$ (Figura 4).

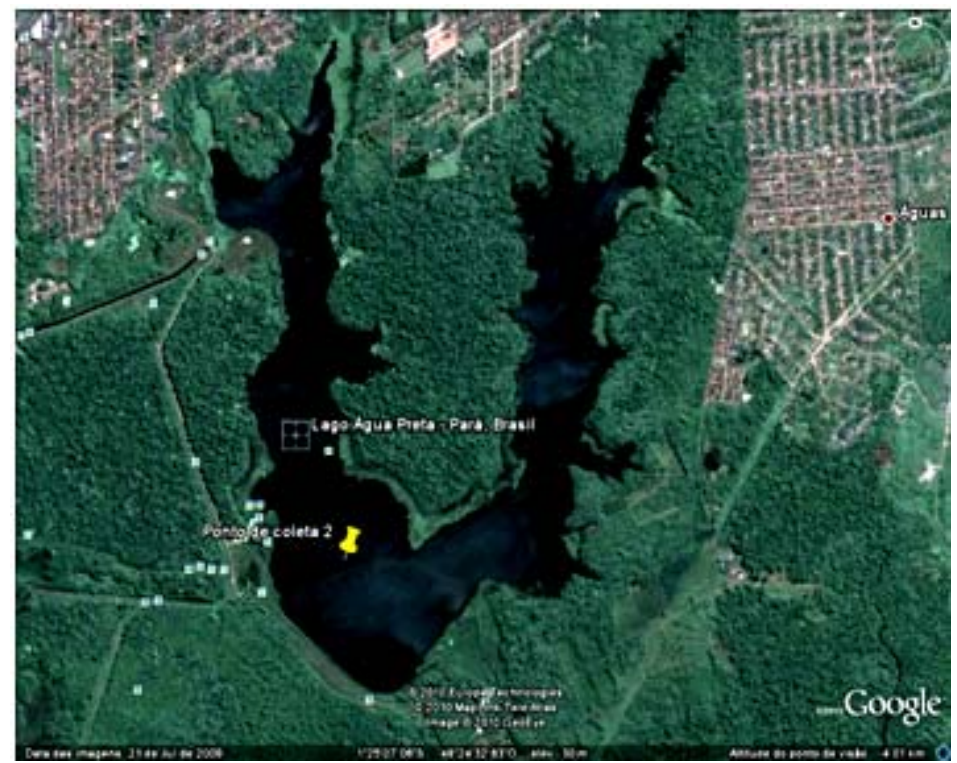

Figura 4. Ponto de coleta 2 na porção inferior esquerda do lado Água Preta.

Fonte: Adaptado de Google Earth (2010).

Ponto de coleta 3 - localizado no lago Bolonha, na parte central, coordenadas 1'25’12.78'’S e 48²5'58.92'’O (Figura 5). 
VASCONCELOS, V. de M. M.; SOUZA, C. F. Caracterização dos parâmetros de qualidade da água do manancial Utinga, Belém, PA, Brasil. Ambi-Agua, Taubaté, v. 6, n. 2, p. 305-324, 2011. (doi:10.4136/ambiagua.202)

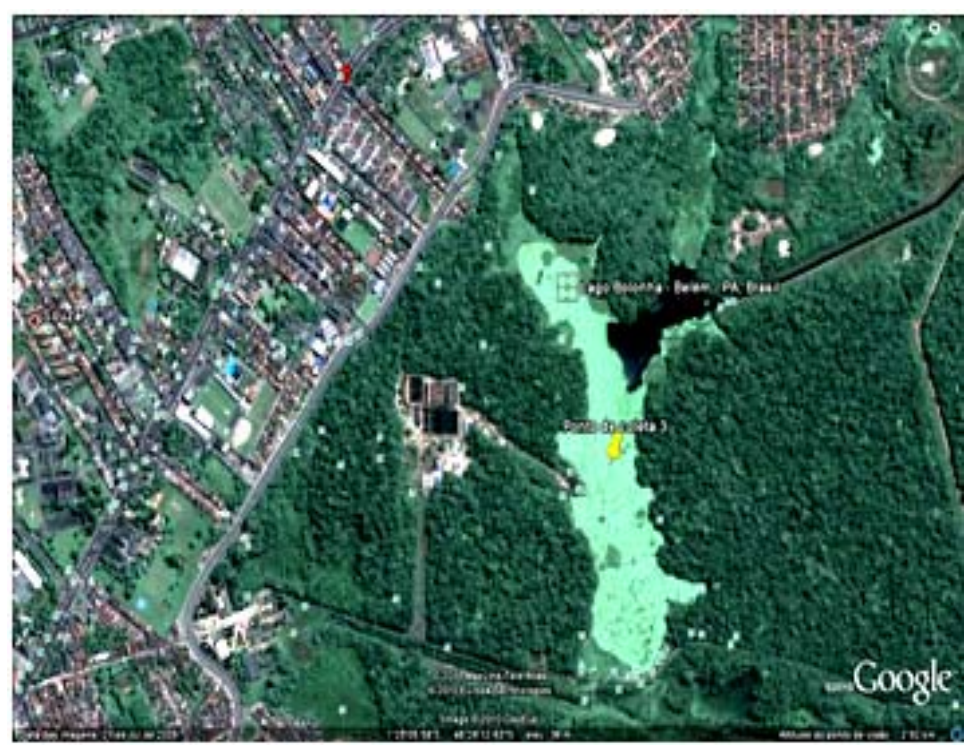

Figura 5. Ponto de coleta 3, parte central do lago Bolonha.

Fonte: Adaptado de Google Earth (2010).

No laboratório UECQ foram realizadas as análises dos seguintes parâmetros: $\mathrm{pH}$, cor, turbidez, cloreto, alcalinidade, amônia, oxigênio dissolvido, coliforme total, dureza total, nitratos e nitritos.

A coleta de água na entrada da ETA Bolonha é realizada de 2 em 2 horas para análises de cor, turbidez, $\mathrm{pH}$, cloro residual e flúor, chamada de análise de rotina. Semanalmente são realizados os tratamentos da alcalinidade, dureza, oxigênio dissolvido e cloretos. E trimestralmente é realizada a contagem de coliforme e a série nitrogenada (Tabela 1).

A metodologia analítica empregada para a análise físico-químico dos parâmetros estudados foi a do Standard Methods for the Examination of Water and Wastewater (APHA, 1998).

Tabela 1. Parâmetros determinados, princípios do método e referência.

\begin{tabular}{l|l}
\hline VARIÁVEL & METODOLOGIA \\
\hline pH & Potenciométrico \\
COR APARENTE & Espectofotométrico \\
TURBIDEZ & Nefelométrico \\
CLORETO & Titulometria argentometria \\
DUREZA & Titulometria com EDTA \\
ALCALINIDADE & Titulação potenciométrica \\
OXIGÊNIO & Titulométrico \\
DISSOLVIDO & Espectrofotométrico do \\
N-AMONIACAL & fenol \\
NITRATOS & Fenoldissulfônico \\
NITRITOS & Colorimétrico da \\
COLIFORME & Alfanaftilamina. \\
TOTAL & Substrato cromogênico \\
\hline
\end{tabular}


VASCONCELOS, V. de M. M.; SOUZA, C. F. Caracterização dos parâmetros de qualidade da água do manancial Utinga, Belém, PA, Brasil. Ambi-Agua, Taubaté, v. 6, n. 2, p. 305-324, 2011. (doi:10.4136/ambiagua.202)

As análises da demanda bioquímica de oxigênio (DBO), demanda química de oxigênio (DQO) e temperatura não estão sendo realizadas pela ausência do aparelho para análises.

\section{RESULTADOS E DISCUSSÃO}

Os resultados dos parâmetros físico-químicos e biológicos analisados foram discutidos e comparados com os valores verificados no período de janeiro de 2007 a setembro de 2009.

Para auxiliar as discussões apresentamos a Figura 6, com os valores da precipitação na região metropolitana de Belém.

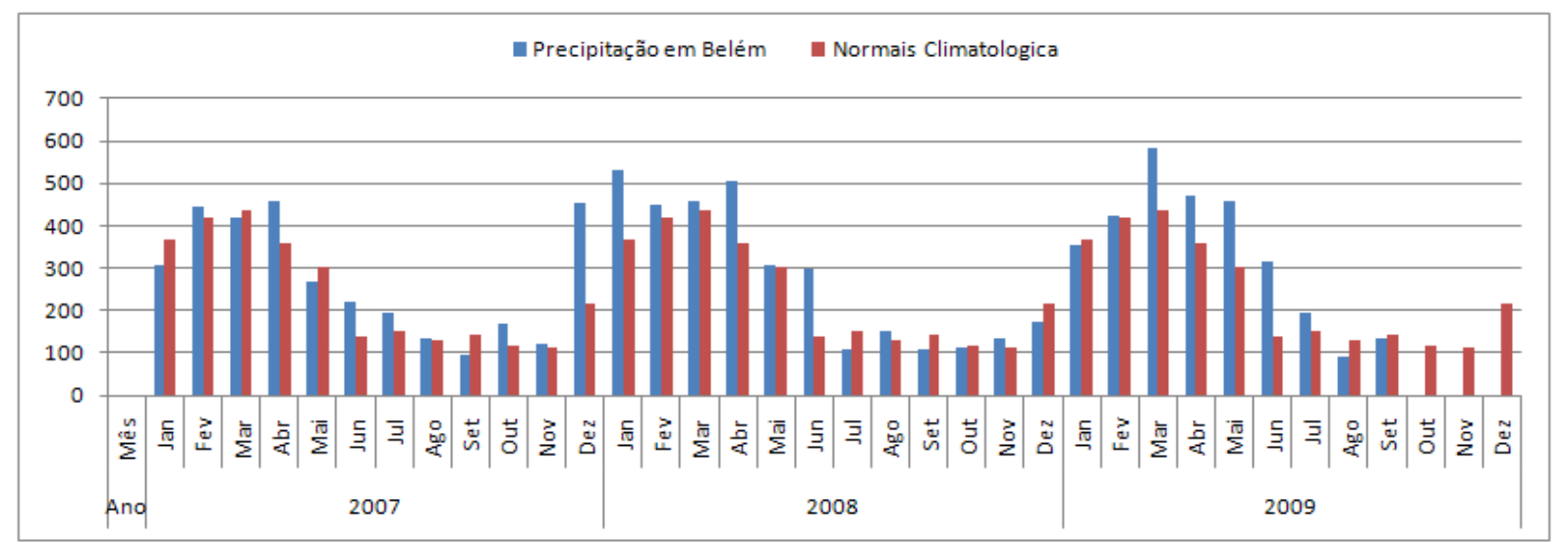

Figura 6. Perfil precipitação (em mm) na Região Metropolitana de Belém.

Fonte: INMET 2011

A média mensal da precipitação na região metropolitana de Belém varia entre 111,8 mm a mínima no mês de novembro e 436,2 mm a máxima no mês de março. A média por ano é de 2893,1 mm.

Na Figura 6, observou-se que os valores do volume da precipitação média na cidade de Belém são maiores nos meses de janeiro, fevereiro março e abril. No período estudado o volume de precipitação foi acima da média nos respectivos meses.

\section{1. $\mathbf{p H}$}

$\mathrm{pH}$, termo usado para expressar a intensidade da condição ácida $(\mathrm{H}+)$ ou alcalina $\mathrm{OH}$ - de uma solução, em termos de concentração de íons de hidrogênio $\mathrm{H}+$ é definido como o logaritmo negativo da concentração molar de íons de hidrogênio.

$\mathrm{pH}=-\log [\mathrm{H}+]$

De acordo com Esteves (1988), o pH pode ser considerado uma das variáveis ambientais mais importantes e complexas de se interpretar, devido ao grande número de fatores que podem influenciá-lo. Em geral, nas águas naturais, o pH é alterado pelas concentrações de íons $\mathrm{H}+$ originados da dissociação do ácido carbônico, que gera valores baixos de $\mathrm{pH}$ e das reações de íons de carbonato e bicarbonato com a molécula de água, que elevam os valores de $\mathrm{pH}$ para a faixa alcalina.

$\mathrm{O} \mathrm{pH}$ da grande maioria dos corpos d'água varia entre 6 e 8. Ecossistemas que apresentam valores baixos de $\mathrm{pH}$ têm elevadas concentrações de ácidos orgânicos dissolvidos de origem alóctone e autóctone. Nesses ecossistemas, são encontradas altas concentrações de ácido sulfúrico, nítrico, oxálico, acético, além de ácido carbônico, formado, principalmente, 
VASCONCELOS, V. de M. M.; SOUZA, C. F. Caracterização dos parâmetros de qualidade da água do manancial Utinga, Belém, PA, Brasil. Ambi-Agua, Taubaté, v. 6, n. 2, p. 305-324, 2011. (doi:10.4136/ambiagua.202)

pela atividade metabólica dos micro-organismos aquáticos. A resolução CONAMA 20 (Brasil, 2005) define para um rio classe II um pH variando de 6 a 9.

No período estudado, o menor valor do $\mathrm{pH}$ foi 6,26 em maio de 2009 e o maior 7,09 em janeiro de 2008. Os valores de $\mathrm{pH}$ apresentam uma pequena variação, observando a distribuição da média por ano de monitoramento, a menor média foi de 6,42 indica o ano de 2009 e a maior, 6,66 no ano de 2008 (Tabela 2).

Tabela 2. Valores médios, máximo e mínimos e Desvio Padrão (DP) de pH na água superficial bruta da ETA Bolonha.

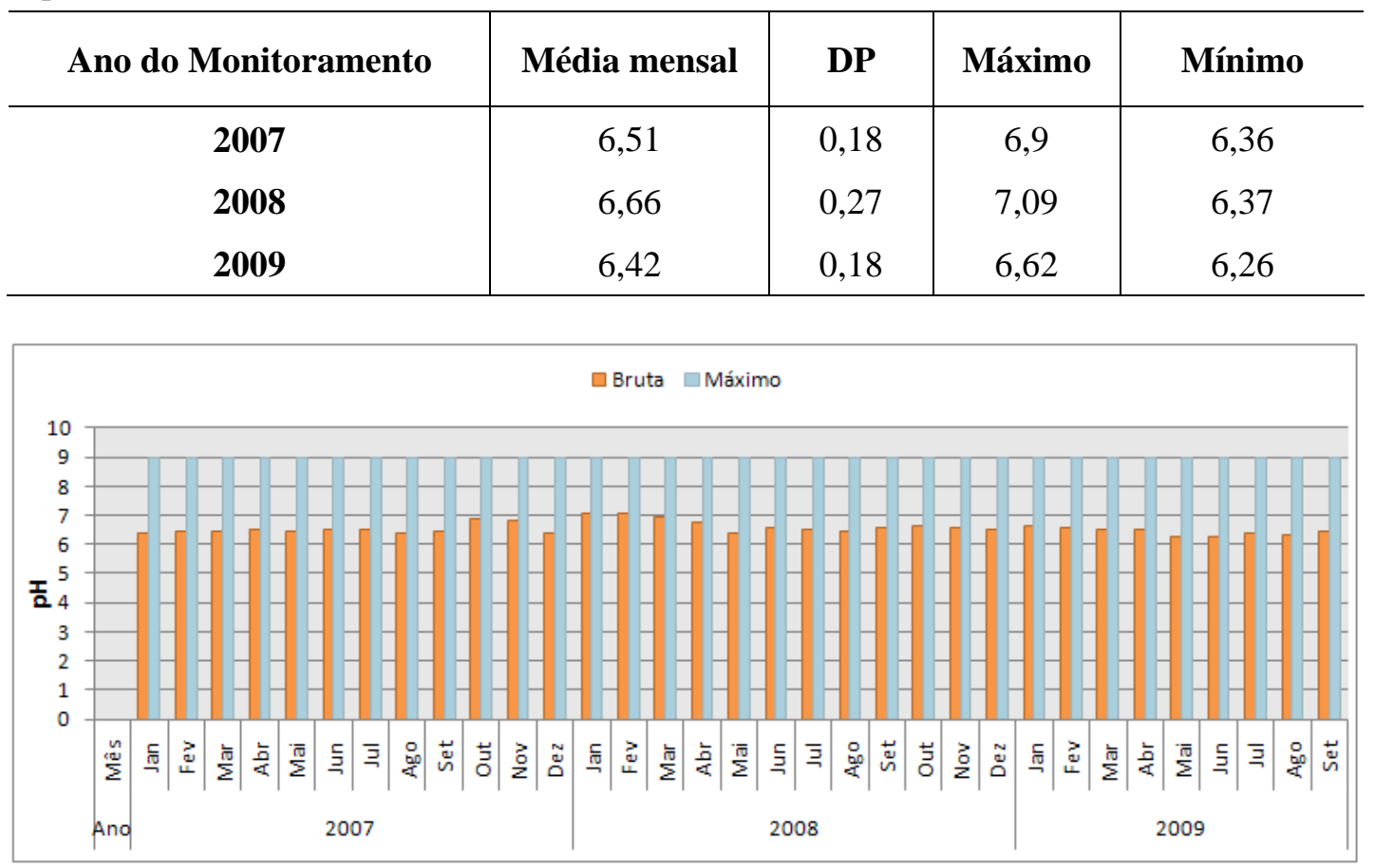

Figura 7. Perfil do $\mathrm{pH}$.

As oscilações do pH estão dentro do intervalo permitido pela Conama 357/05, que recomenda para mananciais valores de $\mathrm{pH}$ em torno de 6,0 a 9,0. O máximo de 7,09 indica um pH da água levemente ácido.

O pH é importante principalmente nas etapas de coagulação, filtração, desinfecção e controle de corrosão.

Considerado como uma das variáveis ambientais mais importantes, o pH é ao mesmo tempo uma das mais difíceis de interpretar, o que se deve ao grande número de fatores que podem influenciá-lo (Esteves, 1988). Sendo assim, em termos de águas residuárias o pH fora da neutralidade tende a afetar as taxas de crescimento dos micro-organismos e, valores elevados podem estar associados à proliferação de algas em corpos d’água.

\subsection{Turbidez}

De acordo com a Tabela 3, o valor máximo de turbidez registrado foi de 25,51 UNT em janeiro de 2009 e o mínimo de 3,36 UNT em agosto de 2008. Os valores da média de turbidez durante o período estudado mostrou a menor média - 6,29 - no ano de 2007 e a maior - 9,44 no ano de 2009.

A Conama 357/05 dita que o limite máximo permitido para o valor da turbidez é de 5 UNT. Em 2008 em 2009, os valores para turbidez variaram muito acima desse limite, na Figura 8 percebe-se melhor essa elevação. 
VASCONCELOS, V. de M. M.; SOUZA, C. F. Caracterização dos parâmetros de qualidade da água do manancial Utinga, Belém, PA, Brasil. Ambi-Agua, Taubaté, v. 6, n. 2, p. 305-324, 2011. (doi:10.4136/ambiagua.202)

Tabela 3. Valores médios, máximo e mínimo e Desvio Padrão (DP) de unidade de turbidez (UNT) na água bruta superficial dos lagos Bolonha, Água Preta e rio Guamá.

\begin{tabular}{c|c|c|c|c}
\hline Ano do Monitoramento & Média mensal & DP & Máximo & Mínimo \\
\hline $\mathbf{2 0 0 7}$ & 6,29 & 1,58 & 8,92 & 3,73 \\
$\mathbf{2 0 0 8}$ & 8,52 & 4,82 & 19,30 & 3,36 \\
$\mathbf{2 0 0 9}$ & 9,44 & 7,78 & 25,51 & 4,37 \\
\hline
\end{tabular}

\subsection{Cor}

O valor máximo de cor registrado foi de 111,63 uH em janeiro de 2009, o menor valor 32,50 uH em janeiro de 2007. Os valores da média da cor durante o período estudado mostrou a menor média - 53,89 - no ano de 2007 e a maior - 81,71 - no ano de 2009 (Tabela 4).

Tabela 4. Valores médios, máximo e mínimo e Desvio Padrão (DP) da cor na água bruta superficial dos lagos Bolonha, Água Preta e rio Guamá.

\begin{tabular}{c|c|c|c|c}
\hline Ano do Monitoramento & Média mensal & DP & Máximo & Mínimo \\
\hline $\mathbf{2 0 0 7}$ & 53,89 & 13,58 & 80,41 & 32,50 \\
$\mathbf{2 0 0 8}$ & 74,12 & 16,22 & 96,06 & 47,82 \\
$\mathbf{2 0 0 9}$ & 81,71 & 18,93 & 111,63 & 50,04 \\
\hline
\end{tabular}

O parâmetro cor foi influenciado diretamente pelas elevações da variável turbidez, podese verificar tanto nas Tabelas 3 e 4 quanto na Figura 8 essa correspondência nos anos 2008/2009.

Os compostos dissolvidos são responsáveis pela cor verdadeira da água e o material em suspensão pela cor aparente (Esteves, 1988).

Segundo a Conama 357/05, o máximo permitido para cor é de $75 \mathrm{uH}$, porém os valores máximos observados no período estudado estão acima do limite permitido, no período de maiores precipitações na região metropolitana de Belém.

Na Figura 8 foi registrada a evolução da cor e turbidez com base na média por ano de amostragem nos pontos de coletas. As alterações dos valores registrados, principalmente fim de 2008 e início de 2009, atribuiram-se a um longo período de estiagem, seguido da estação de maior precipitação na cidade de Belém. A chuva arrastou para o manancial do Utinga maiores quantidade de lixos, deixados nas ruas, lançados e/ou acumulados no corpo d’água e, com isso, as águas do manancial vêm sofrendo alterações na sua qualidade.

O período de estiagem citado acima interferiu na vazão do rio Guamá, reduzindo o nível de água dos Lagos Água Preta e Bolonha consideravelmente. E o acúmulo de lixos e sedimentos no fundo dos lagos, comprometeu também o poder de diluição dos poluentes na água.

A quantidade de sedimentos encontrados no fundo do rio juntamente com barrancos e sedimentos levados pela força das águas do rio Guamá para o manancial, faz com que haja a presença de partículas insolúveis do solo, matéria orgânica, micro-organismos e outros materiais diversos que provocam a dispersão e a absorção da luz, dando à água uma aparência nebulosa, esteticamente indesejável. 
VASCONCELOS, V. de M. M.; SOUZA, C. F. Caracterização dos parâmetros de qualidade da água do manancial Utinga, Belém, PA, Brasil. Ambi-Agua, Taubaté, v. 6, n. 2, p. 305-324, 2011. (doi:10.4136/ambiagua.202)

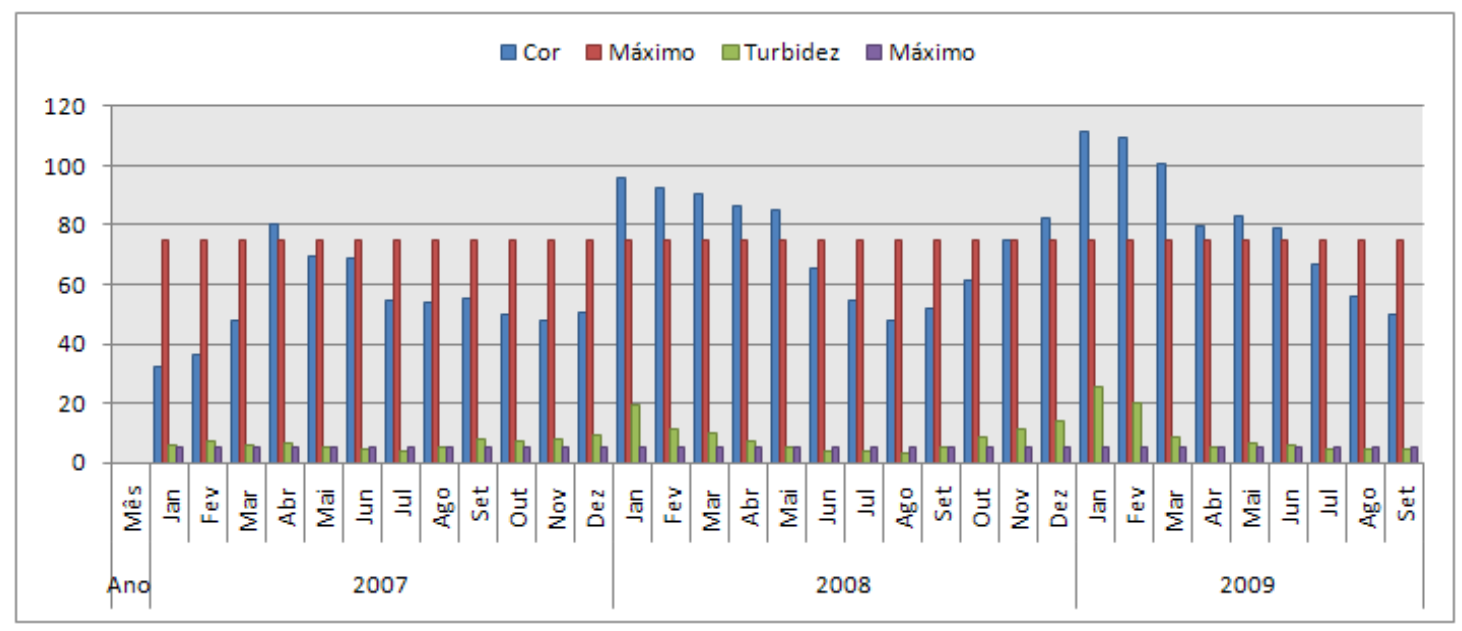

Figura 8. Evolução dos parâmetros Cor e Turbidez.

Ainda foi possível notar na Figura 8 que os valores registrados para cor e turbidez estão aumentando a cada novo ano. Isso remete a uma preocupação em relação à sustentabilidade do manancial e à permanência no enquadramento Classe 2 de águas para abastecimento. É bem possível que, continuando os valores de cor/turbidez a aumentar nessa proporção, daqui a algum tempo as águas do manancial do Utinga se tornarão inadequadas para o consumo da população belenense.

Santos et al. (2005) verificaram valores de turbidez no Lago Água Preta, entre 4,01 UNT e 88,00 UNT, sendo o maior valor observado em uma coleta realizada próxima ao rio Guamá. Sodré (2007) encontrou valores de turbidez nos lagos Bolonha e Água Preta variando entre 4 UNT e 59 UNT. Esses autores relacionam esse máximo valor como consequência da influência direta das águas do rio Guamá.

\subsection{Oxigênio Dissolvido}

O oxigênio dissolvido é indispensável à sobrevivência dos organismos aeróbios. A água, em condições normais, contém oxigênio dissolvido cujo teor de saturação, pela lei de Henry, depende da pressão parcial de vapor do gás e da temperatura. Assim, águas com baixos teores de oxigênio dissolvido indicam presença de sólidos, pois a decomposição da matéria orgânica pelas bactérias aeróbias é acompanhada pelo consumo do oxigênio dissolvido da água e, dependendo da capacidade de autodepuração do manancial, o teor de oxigênio dissolvido pode alcançar valores baixos, ou mesmo zero, extinguindo-se os organismos aquáticos aeróbios.

O maior valor de oxigênio dissolvido registrado foi 9,0 mg/L $0_{2}$ em fevereiro de 2008, na água bruta do Rio Guamá e o menor $1,0 \mathrm{mg} / \mathrm{L} 0_{2}$, em dezembro no rio Guamá em agosto e dezembro no Lago Água Preta e em agosto no Lago Bolonha. Os valores da média do oxigênio dissolvido durante o período estudado mostrou a menor média - 1,49 mg/L - no ano de 2009, no Lago Bolonha e a maior - 4,51 mg/L - no ano de 2008 no Rio Guamá (Tabela 5).

Na Tabela 5, observou-se que no ano de 2008 foram registrados os mais elevados valores para oxigênio dissolvido encontrados nos lagos Água Preta e Bolonha, próximos aos valores permitidos para ETAs, estabelecido no Art.15, V, da Resolução Conama 357/05, que dispõe sobre a classificação dos corpos de água e diretrizes ambientais para o seu enquadramento no território nacional. 
VASCONCELOS, V. de M. M.; SOUZA, C. F. Caracterização dos parâmetros de qualidade da água do manancial Utinga, Belém, PA, Brasil. Ambi-Agua, Taubaté, v. 6, n. 2, p. 305-324, 2011. (doi:10.4136/ambiagua.202)

Tabela 5. Valores médios, máximo e mínimo e Desvio Padrão (DP) de oxigênio dissolvido da água bruta superficial dos lagos Bolonha, Água Preta e Rio Guamá.

\begin{tabular}{c|c|c|c|c}
\hline $\begin{array}{c}\text { Ano do } \\
\text { monitoramento }\end{array}$ & Valores & Rio Guáma & L. Água Preta & L. Bolonha \\
\hline \multirow{3}{*}{$\mathbf{2 0 0 7}$} & Média & 4,47 & 3,65 & 2,98 \\
& DP & 2,45 & 1,44 & 1,30 \\
& Máximo & 8,4 & 6,0 & 5,4 \\
& Mínimo & 1,2 & 1,2 & 1,8 \\
\hline \multirow{3}{*}{$\mathbf{2 0 0 8}$} & Média & 4,9 & 4,45 & 4,51 \\
& DP & 2,92 & 2,50 & 2,36 \\
& Máximo & 9,0 & 8,2 & 9,2 \\
& Mínimo & 1,0 & 1,6 & 1,2 \\
\hline \multirow{3}{*}{$\mathbf{2 0 0 9}$} & Média & 2,86 & 2,34 & 1,49 \\
& DP & 1,36 & 1,13 & 0,47 \\
& Máximo & 4,8 & 4,0 & 2,2 \\
& Mínimo & 1,0 & 1,0 & 1,0 \\
\hline
\end{tabular}

Foi verificado também que a maior média de oxigênio dissolvido se encontra nas águas do rio Guamá, porém em fevereiro, março e agosto de 2008, os valores do lago Bolonha superaram os encontrados no lago Água Preta e rio Guamá, como mostra a Figura 9, no mesmo período. Sabendo-se que a água do lago Bolonha é a mistura das águas do rio Guamá e lago Água Preta, se nesse período a alteração foi maior, poderão as águas do lago Bolonha estarem sendo influenciadas pela ação direta da população que vive no entorno do manancial, especificamente aqueles situados nas proximidades do respectivo lago. Segundo Di Bernardo et al. (2002), a poluição do meio aquático pode causar alterações nas características físicas (turbidez, cor, número e tamanho de partículas, temperatura, condutividade, viscosidade, tensão superficial etc), químicas (DBO, DQO, pH, toxicidade etc) ou biológicas (espécies de fitoplâncton e do zooplâncton).

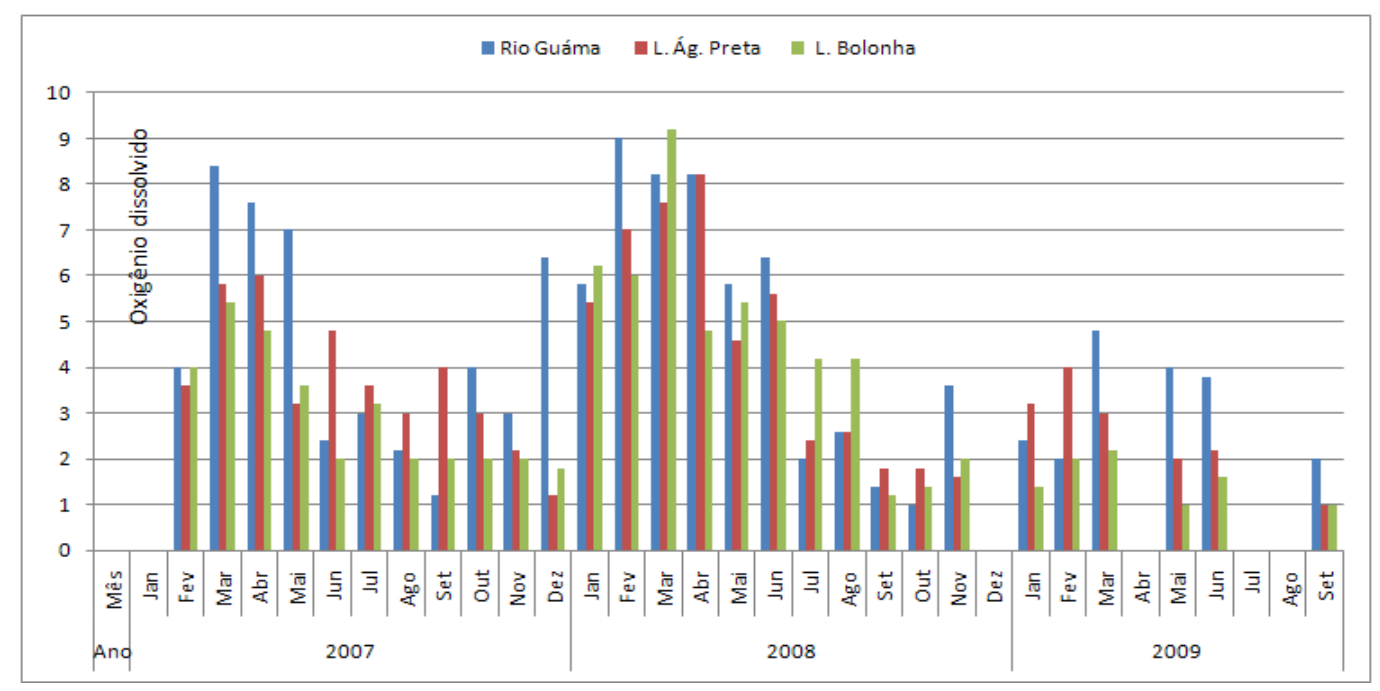

Figura 9. Perfil do oxigênio dissolvido.

A população no entorno do Manancial do Utinga tem crescido e violado o cinturão de isolamento (muro) do manancial. Parte do esgoto dessa população passa por debaixo do muro e contamina o lago Bolonha, que se encontra em estado de eutrofização. 
VASCONCELOS, V. de M. M.; SOUZA, C. F. Caracterização dos parâmetros de qualidade da água do manancial Utinga, Belém, PA, Brasil. Ambi-Agua, Taubaté, v. 6, n. 2, p. 305-324, 2011. (doi:10.4136/ambiagua.202)

Observou-se na Figura 9 que a maior incidência de quantidades de oxigênio dissolvido no manancial do Utinga ocorre nos meses de maior precipitação, de janeiro a março (Figura 6). Esse parâmetro de oxigênio dissolvido acaba sendo o maior indicador da poluição gerada pela atividade antrópica, e resulta do lançamento de águas residuárias sanitárias, que gera constituintes orgânicos e contribui para a diminuição do oxigênio na água.

\subsection{Coliforme Total}

O valor máximo do coliforme total registrado foi de 92,7x10 3 NMP, em julho, nas águas do rio Guáma, e Lago Água Preta, em abril de 2008. O mínimo foi de 0,346 x $10^{3} \mathrm{NMP}$, em outubro de 2008, no lago Água Preta. A média de coliformes totais encontrados durante o período estudado foi a menor, $8 \times 10^{3} \mathrm{NMP}$, no ano 2007, nas águas do Lago Bolonha. $\mathrm{E}$ a maior, 35,3 x $10^{3}$ NMP, no ano 2008, nas águas do Rio Guáma (Tabela 6).

Os valores do DP apresentados na Tabela 6 acima da média foram devidos à disparidade dos valores em cada amostra/mês. Por meio do valor mínimo e o máximo de coliforme total em cada ano, o valor da DP tende a convergir para o maior, observou-se esta situação em 2007 nos lagos Bolonha e Água Preta e em 2008 no rio Guamá e lago Água Preta. Também a falta de regularidade nos monitoramentos do manancial influenciou para que os valores da DP estejam acima da média. Em 2008 e 2009, foram realizadas monitoramento por apenas 10 e 7 meses respectivamente durante um ano.

Tabela 6. Valores médios, máximo e mínimo e Desvio Padrão (DP) do Coliforme Total da água bruta superficial dos lagos Bolonha, Água Preta e Rio Guamá.

\begin{tabular}{c|c|c|c|c}
\hline $\begin{array}{c}\text { Ano do } \\
\text { monitoramento }\end{array}$ & $\begin{array}{c}\text { Valores } \\
\left.\mathbf{( 1 0}^{3}\right)\end{array}$ & Rio Guamá & L. Água Preta & L. Bolonha \\
\hline \multirow{4}{*}{$\mathbf{2 0 0 7}$} & Média & 17,90 & 12,17 & 8,02 \\
& DP & 16,46 & 18,21 & 16,71 \\
& Máximo & 54,00 & 35,00 & 54,00 \\
& Mínimo & 2,60 & 0,40 & 1,00 \\
\hline \multirow{3}{*}{2008} & Média & 35,31 & 28,50 & 16,83 \\
& DP & 37,25 & 37,35 & 16,46 \\
& Máximo & 92,70 & 92,00 & 54,00 \\
& Mínimo & 3,30 & 0,34 & 3,10 \\
\hline \multirow{3}{*}{$\mathbf{2 0 0 9}$} & Média & 27,48 & 8,68 & 9,61 \\
& DP & 21,56 & 5,25 & 17,83 \\
& Máximo & 54,00 & 38,00 & 48,84 \\
& Mínimo & 3,41 & 1,01 & 5,24 \\
\hline
\end{tabular}

Foi possível observar que a evolução dos valores de coliforme total está semelhante à evolução dos valores de oxigênio dissolvido, pois águas de superfície, relativamente límpidas, apresentam-se saturadas de oxigênio dissolvido, porém este pode ser rapidamente consumido pela demanda de oxigênio dos esgotos domésticos. A maior média de coliforme esteve presente nas águas do rio Guamá,como mostra a Tabela 6 e Figura 10. As quantidades presentes nas águas do rio Guamá e lago Água Preta em abril, maio, julho e agosto de 2008 são basicamente as mesmas. 
VASCONCELOS, V. de M. M.; SOUZA, C. F. Caracterização dos parâmetros de qualidade da água do manancial Utinga, Belém, PA, Brasil. Ambi-Agua, Taubaté, v. 6, n. 2, p. 305-324, 2011. (doi:10.4136/ambiagua.202)

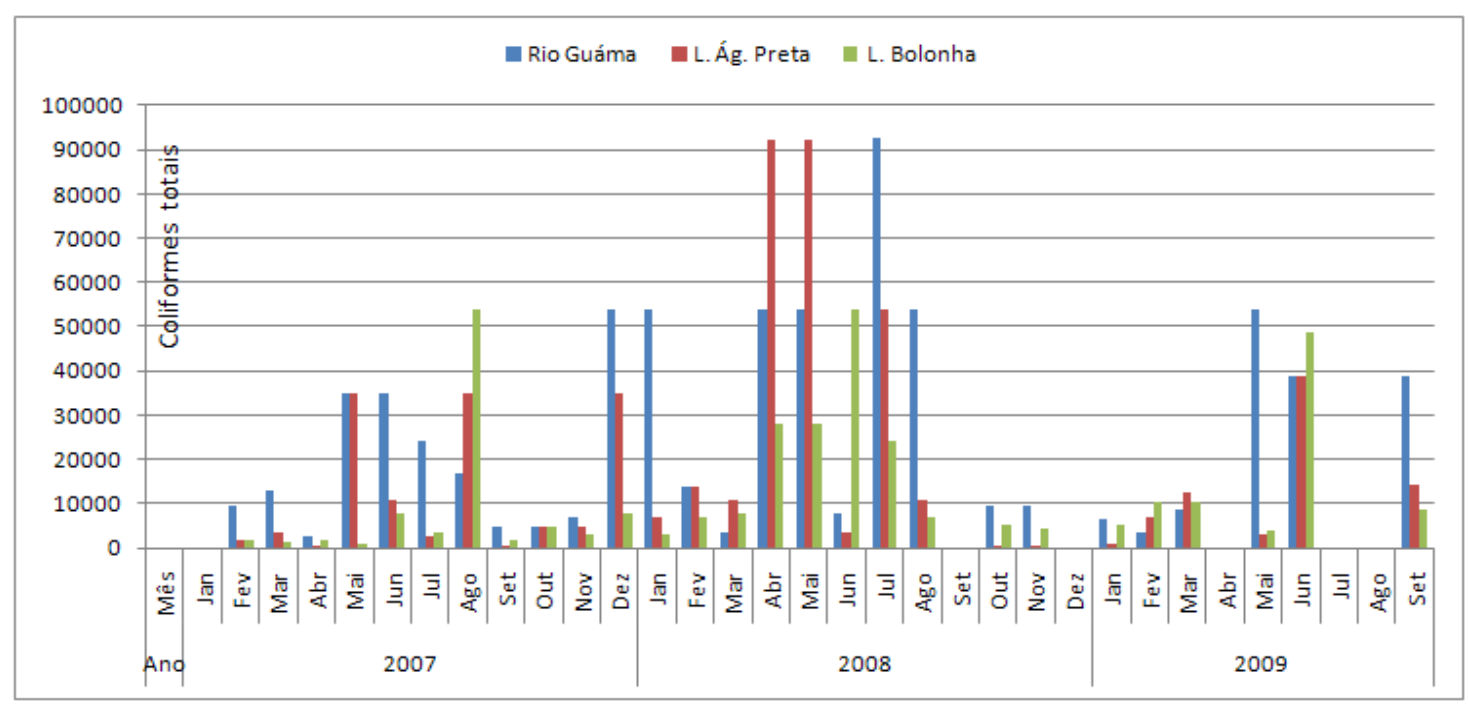

Figura 10. Perfil coliforme total MNP/100 ml.

Segundo a Resolução Conama 357/05, o valor máximo de coliformes totais é de 5.000 e coliformes termotolerantes para águas de mananciais é de 1000 por No/100 mL.

Em agosto de 2007, a quantidade de coliforme total verificado no lago Bolonha superou os valores encontrados no lago Água Preta e no rio Guamá. Já nos meses seguinte, as alterações para mais correspondem às águas do lago Água Preta e rio Guamá. Ou seja, mais uma vez pode-se deduzir a existência de outros focos de contaminação na água do lago Bolonha.

Mediante a época das chuvas e do fluxo de marés, ocorre a oscilação dos níveis de poluentes na água. Em Belém, no período de maior precipitação Figura 6, o índice de poluição aumenta nos reservatórios.

Também o volume de poluição tende a ser maior por parte da ação antrópica dos moradores da região metropolitana de Belém. O esgoto produzido na cidade é lançado na baía do Guajará e rio Guamá, que ainda sem tratamento é levado pelo rio Guamá para o manancial do Utinga.

Em 2002, Matta (2002) analisou as águas do rio Guamá e verificou, próximo à cidade de Belém, o índice de coliforme total entre 4300 e 9300 NMP e coliforme termotolerante entre 430 e 750 NMP. Considerando o autor que essas substâncias influenciam nos lagos Bolonha e Água Preta, justamente por causa das águas do rio Guamá abastecê-los através de uma adutora.

A cidade de Belém possui uma ETE, que fica localizado no bairro da Marambaia e que em projeto vai atender à população que reside próximo ao manancial, ou seja, Lago Bolonha. Porém por questões burocráticas a ETE ainda não se encontra em funcionamento.

\subsection{Dureza Total}

O valor máximo da dureza total registrada foi de $40 \mathrm{mg} / \mathrm{L} \mathrm{CaC0}_{3}$ em novembro de 2007 na água bruta do Rio Guamá e o mínimo de 4,0 mg/L $\mathrm{CaC0}_{3}$ em junho de 2009 no Rio Guamá. Os valores da média da dureza total, durante o período estudado, mostrou a menor média, 10 mg/L no ano de 2009 no Rio Guamá e a maior, 20,91 no ano de 2007 no Lago Bolonha (Tabela 7 e Figura 11). 
VASCONCELOS, V. de M. M.; SOUZA, C. F. Caracterização dos parâmetros de qualidade da água do manancial Utinga, Belém, PA, Brasil. Ambi-Agua, Taubaté, v. 6, n. 2, p. 305-324, 2011. (doi:10.4136/ambiagua.202)

Tabela 7. Valores médios, máximo e mínimo e Desvio Padrão (DP) da Dureza Total da água bruta superficial dos lagos Bolonha, Água Preta e Rio Guamá.

\begin{tabular}{c|c|c|c|c}
\hline $\begin{array}{c}\text { Ano do } \\
\text { monitoramento }\end{array}$ & Valores & Rio Guamá & L. Água Preta & L. Bolonha \\
\hline \multirow{3}{*}{2007} & Média & 18,18 & 18 & 20,91 \\
& DP & 9,57 & 5,66 & 8,12 \\
& Máximo & 40 & 30 & 36 \\
& Mínimo & 6 & 10 & 8 \\
\hline \multirow{3}{*}{$\mathbf{2 0 0 8}$} & Média & 14 & 13,4 & 14,2 \\
& DP & 3,83 & 3,04 & 3,05 \\
& Máximo & 20 & 18 & 20 \\
& Mínimo & 10 & 10 & 10 \\
\hline \multirow{3}{*}{$\mathbf{2 0 0 9}$} & Média & 10 & 10,57 & 12 \\
& DP & 3,46 & 2,76 & 2,83 \\
& Máximo & 14 & 16 & 14 \\
& Mínimo & 4 & 8 & 8 \\
\hline
\end{tabular}

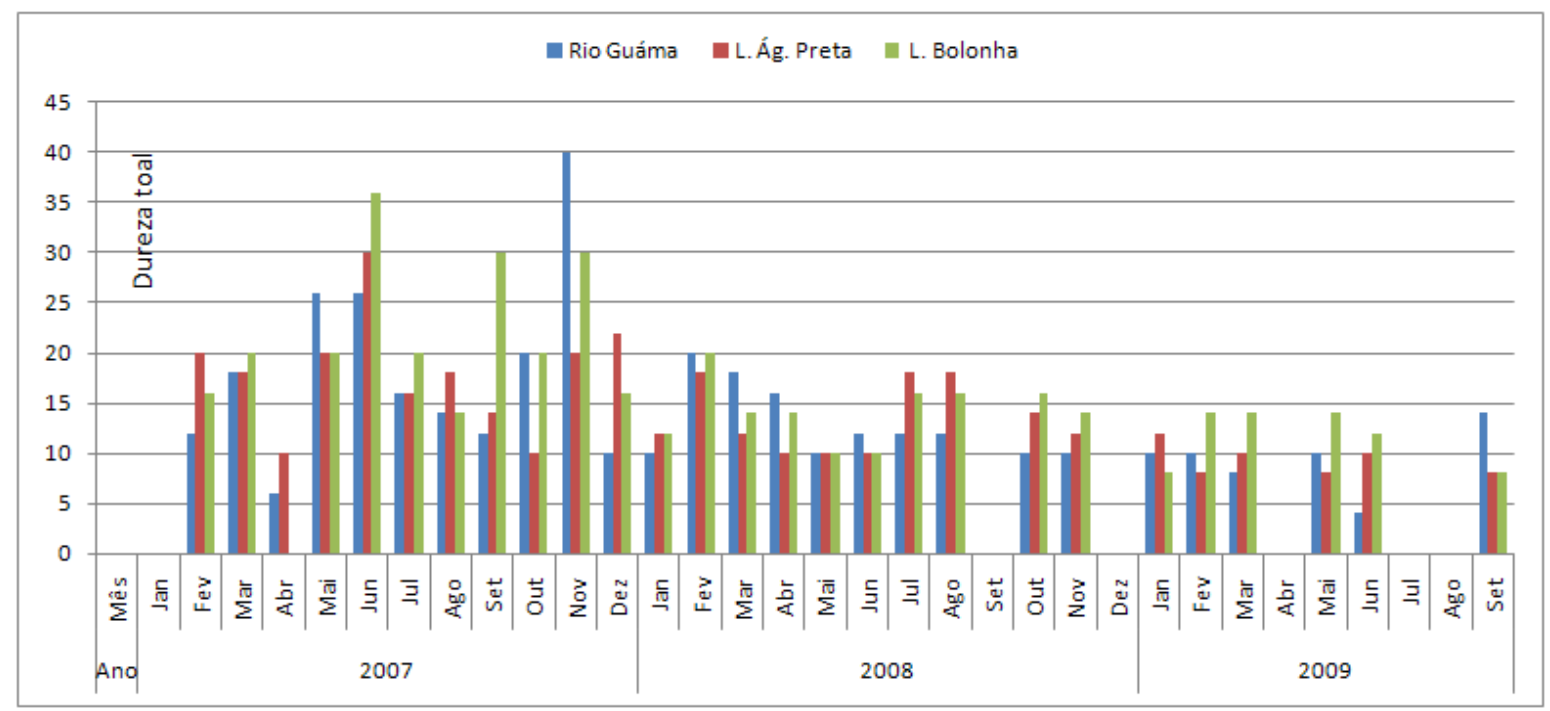

Figura 11. Perfil dureza total (mg/L $\left.\mathrm{CaCO}_{3}\right)$.

A dureza é caracterizada pela presença de sais de metais alcalinos terrosos (cálcio e magnésio), ferro e manganês, ou de outros metais bivalentes, em menor intensidade, em teores elevados, causa sabor desagradável e efeitos laxantes. Os valores registrados foram menores que 50 mg/L, logo a água é classificada como, água mole.

A precipitação química elimina uma parte da dureza e minerais dissolvidos (Fe e Mn).

\subsection{Nitratos}

O nitrato é a principal forma de nitrogênio configurado encontrado nas águas e é produzido no sistema aquático pelo processo de nitrificação a partir da matéria orgânica nitrogenada. 
VASCONCELOS, V. de M. M.; SOUZA, C. F. Caracterização dos parâmetros de qualidade da água do manancial Utinga, Belém, PA, Brasil. Ambi-Agua, Taubaté, v. 6, n. 2, p. 305-324, 2011. (doi:10.4136/ambiagua.202)

O valor máximo do nitrato registrada foi de $0,35 \mathrm{mg} / \mathrm{L} \mathrm{N}_{3}$ em outubro e novembro de 2007 na água bruta do Lago Bolonha e o mínimo de $0,05 \mathrm{mg} / \mathrm{L} \mathrm{N0}_{3}$ em janeiro no rio Guáma e Lago Água Preta. Os valores da média do nitrato no período mostraram a menor média, $0,13 \mathrm{mg} / \mathrm{L} \mathrm{N0}$ no ano de 2009 no Lago Bolonha e a maior, 0,21 mg/L N0 ${ }_{3}$ no ano de 2008 no Rio Guamá (Tabela 8).

Segundo a Resolução Conama 357/05, o valor máximo para águas de mananciais é de 10 $\mathrm{mg} / \mathrm{L}$, porém os valores encontrados nas águas do manancial do Utinga estão abaixo do valor máximo verificando na Tabela 8.

Segundo trabalhos realizados de 1980 a 1982, por Braz (1985 apud Sodré, 2007), os teores de nitrato oscilaram de $0,01 \mathrm{mg} / \mathrm{L}$ a $0,04 \mathrm{mg} / \mathrm{L}$ no lago Bolonha. No lago Água Preta foi encontrado por Aguiar (2004 apud Sodré, 2007) um valor mais elevado em comparação ao Bolonha, de - 0,08 mg/L no ano de 2003 e de 2004.

Tabela 8. Valores médios, máximo e mínimo e Desvio Padrão (DP) dos nitratos da água bruta superficial dos lagos Bolonha, Água Preta e Rio Guamá.

\begin{tabular}{c|c|c|c|c}
\hline $\begin{array}{c}\text { Ano do } \\
\text { monitoramento }\end{array}$ & Valores & Rio Guamá & L. Água Preta & L. Bolonha \\
\hline \multirow{3}{*}{2007} & Média & 0,16 & 0,15 & 0,19 \\
& DP & 0,10 & 0,06 & 0,09 \\
& Máximo & 0,25 & 0,28 & 0,35 \\
& Mínimo & 0,06 & 0,07 & 0,1 \\
\hline \multirow{3}{*}{$\mathbf{2 0 0 8}$} & Média & 0,21 & 0,16 & 0,22 \\
& DP & 0,15 & 0,06 & 0,09 \\
& Máximo & 0,6 & 0,25 & 0,4 \\
& Mínimo & 0,1 & 0,06 & 0,08 \\
\hline \multirow{3}{*}{2009} & Média & 0,19 & 0,18 & 0,13 \\
& DP & 0,16 & 0,15 & 0,04 \\
& Máximo & 0,5 & 0,5 & 0,2 \\
& Mínimo & 0,05 & 0,05 & 0,1 \\
\hline
\end{tabular}

Todos os valores verificados na Figura 12 estão abaixo do valor máximo permitido pela Conama 357/05. Em dezembro/08 e abril, julho, agosto, setembro/09 não foi realizado o monitoramento das águas do manancial do Utinga.

Entretanto, Cardoso et al. (2009) identificaram o surgimento de macrófitas no Lago Água Preta no ano de 2006, como mostra a Figura 13. Esteves (1988) atribui a proliferação das macróficas a ambientes com altas concentrações de nutrientes como Fósforo e Nitrato.

O nitrogênio, quando descarregado nas águas naturais, conjuntamente com o fósforo e outros nutrientes presentes nos despejos sanitários, provoca enriquecimento do meio, e a proliferação especialmente das algas.

Segundo a resolução Conama 357/05, cianobactérias são micro-organismos procarióticos autotróficos, também denominados como cianofíceas (algas azuis) capazes de ocorrer em qualquer manancial superficial especialmente naqueles com elevados níveis de nutrientes (nitrogênio e fósforo), podendo produzir toxinas com efeitos adversos à saúde. 
VASCONCELOS, V. de M. M.; SOUZA, C. F. Caracterização dos parâmetros de qualidade da água do manancial Utinga, Belém, PA, Brasil. Ambi-Agua, Taubaté, v. 6, n. 2, p. 305-324, 2011. (doi:10.4136/ambiagua.202)

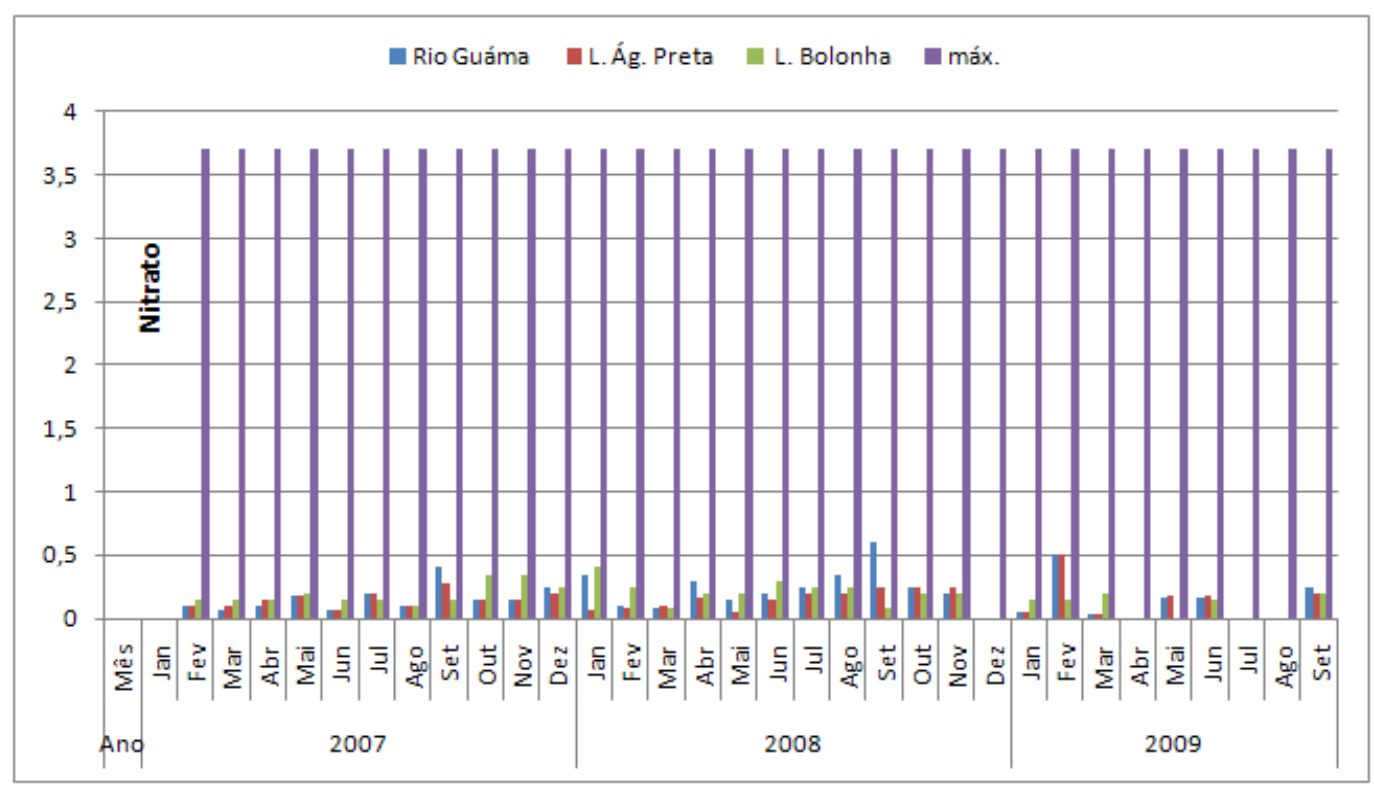

Figura 12. Perfil Nitrato (mg/L NO$\left.{ }_{3}\right)$.

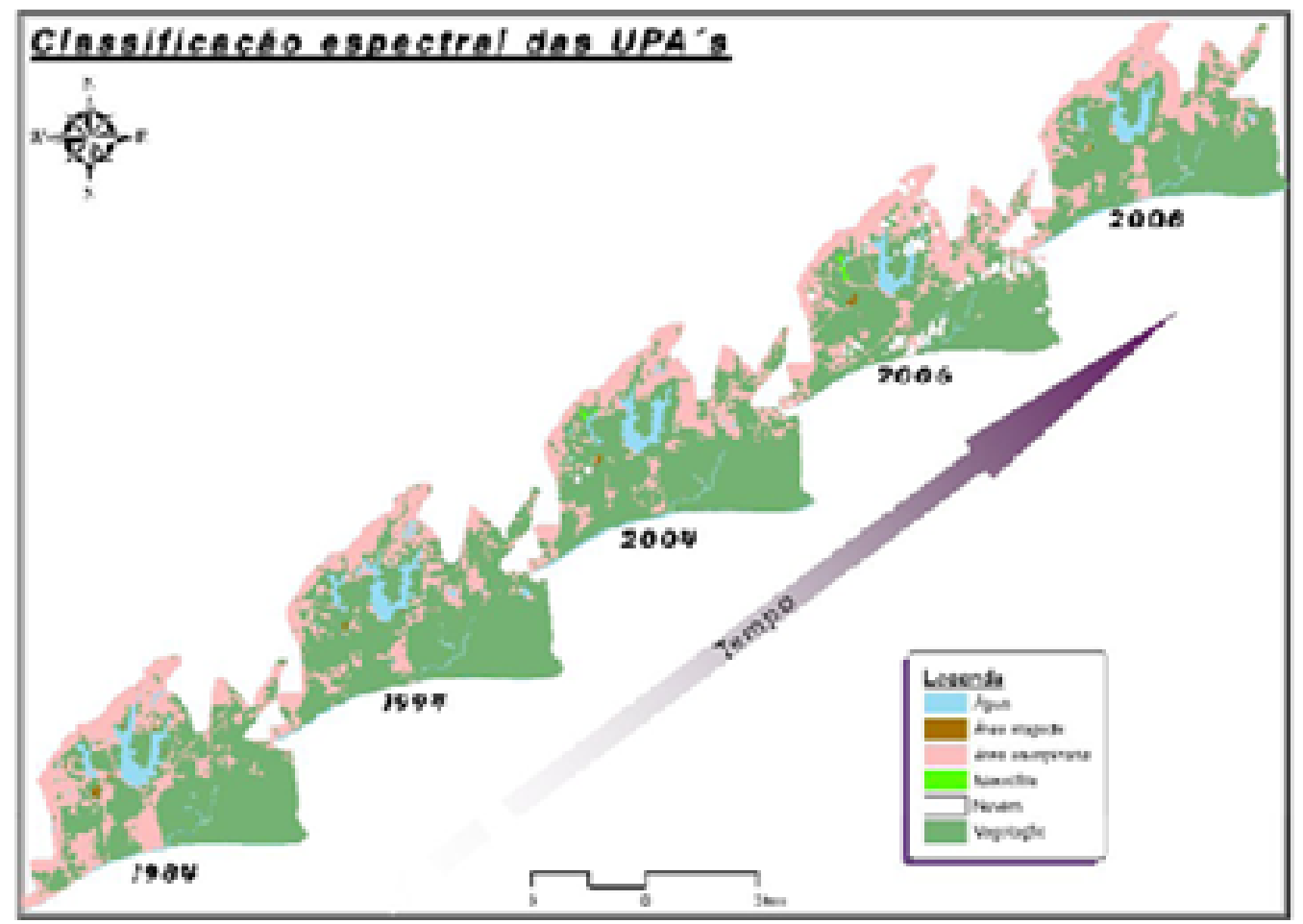

Figura 13. Variação temporal das áreas antropizadas ao longo da linha do tempo.

Fonte: Cardoso et al. (2009).

Foi possível verificar, principalmente no Lago Bolonha (Figura 14), a proliferação das macrófitas cobrindo aproximadamente $85 \%$ da área do lago.

A responsabilidade em relação ao manancial do Utinga é dividida entre as instituições: COSANPA, SEMA e IBAMA. No entanto, a COSANPA, em 2009, realizou uma limpeza para retirada das macrófitas do lago, porém não concluiu devido à insuficiência de verbas e por haver uma indefinição com relação a quem de fato é a responsabilidade da manutenção dos lagos Bolonha e Água Preta. A equipe responsável fez a contenção do material no próprio 
VASCONCELOS, V. de M. M.; SOUZA, C. F. Caracterização dos parâmetros de qualidade da água do manancial Utinga, Belém, PA, Brasil. Ambi-Agua, Taubaté, v. 6, n. 2, p. 305-324, 2011. (doi:10.4136/ambiagua.202)

lago Bolonha, no entanto, a força da vegetação rompeu e as macrófitas cobriram a região do lago.

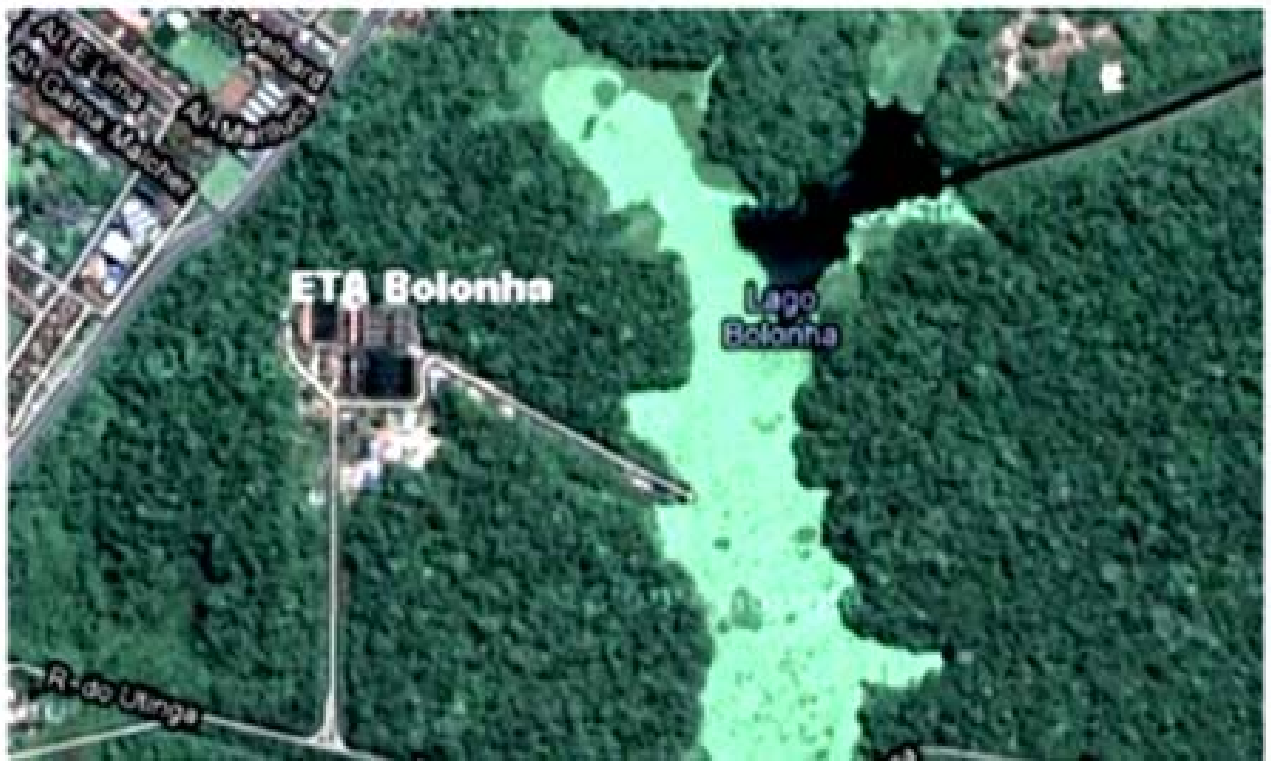

Figura 14. Eutrofização do Lago Bolonha.

Fonte: Google Earth (2010).

Por outro lado, com a falta de coleta de lixo, os moradores do entorno do Lago continuam jogando lixo por cima do muro de isolamento ou queimando-o.

Tundisi e Matsumura-Tundisi (1992), Nascimento (2005), Figueiredo et al. (2007), atribuem a causa da formação de macrófitas em lagos brasileiros a despejos de descargas domésticas e/ou industriais.
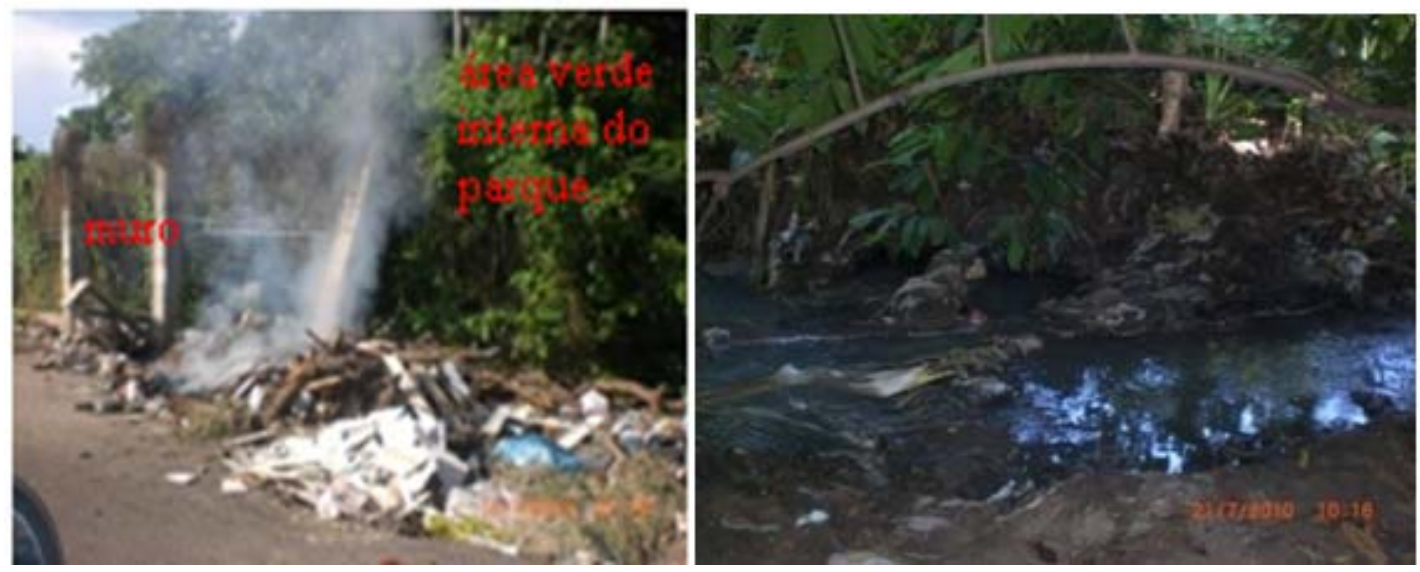

Figura 15. Lixo lançado pela população e esgotos que correm dentro da APA do Utinga.

Foto: feita por Vanilda Vasconcelos em 2010.

A Figura 15 mostra a ausência de coleta de lixo da população que vive no entorno do parque ambiental, onde se encontram os reservatórios de água que abastecem a cidade de Belém. Dentro do parque foi possível encontrar boca de esgoto que vem de bairros distantes da APA e corre direto para o Lago Bolonha, assim como os esgotos dos moradores das proximidades do local. 
VASCONCELOS, V. de M. M.; SOUZA, C. F. Caracterização dos parâmetros de qualidade da água do manancial Utinga, Belém, PA, Brasil. Ambi-Agua, Taubaté, v. 6, n. 2, p. 305-324, 2011. (doi:10.4136/ambiagua.202)

\section{8. $\mathbf{N}$ - Amoniacal}

Segundo a resolução do Conama 357/05, o valor limite do nitrogênio amoniacal varia conforme o valor do $\mathrm{pH}$. As água do manancial do Utinga apresentam $\mathrm{pH}<7,5$. Na Figura 16, verificou-se que os valores não ultrapassam o valor limite permitido. Mota (1995) salienta que nitrogênio orgânico e amônia estão associados a efluentes e águas recém- poluídas. Com o passar do tempo, o nitrogênio orgânico é convertido em nitrogênio amoniacal e, posteriormente, se condições aeróbias estão presentes, a oxidação da amônia acontece transformando-se em nitrito e nitrato. Conforme ressalta Von Sperling (1996), em um corpo d’água, a determinação da parcela predominante de nitrogênio pode fornecer informações sobre o estágio da poluição.

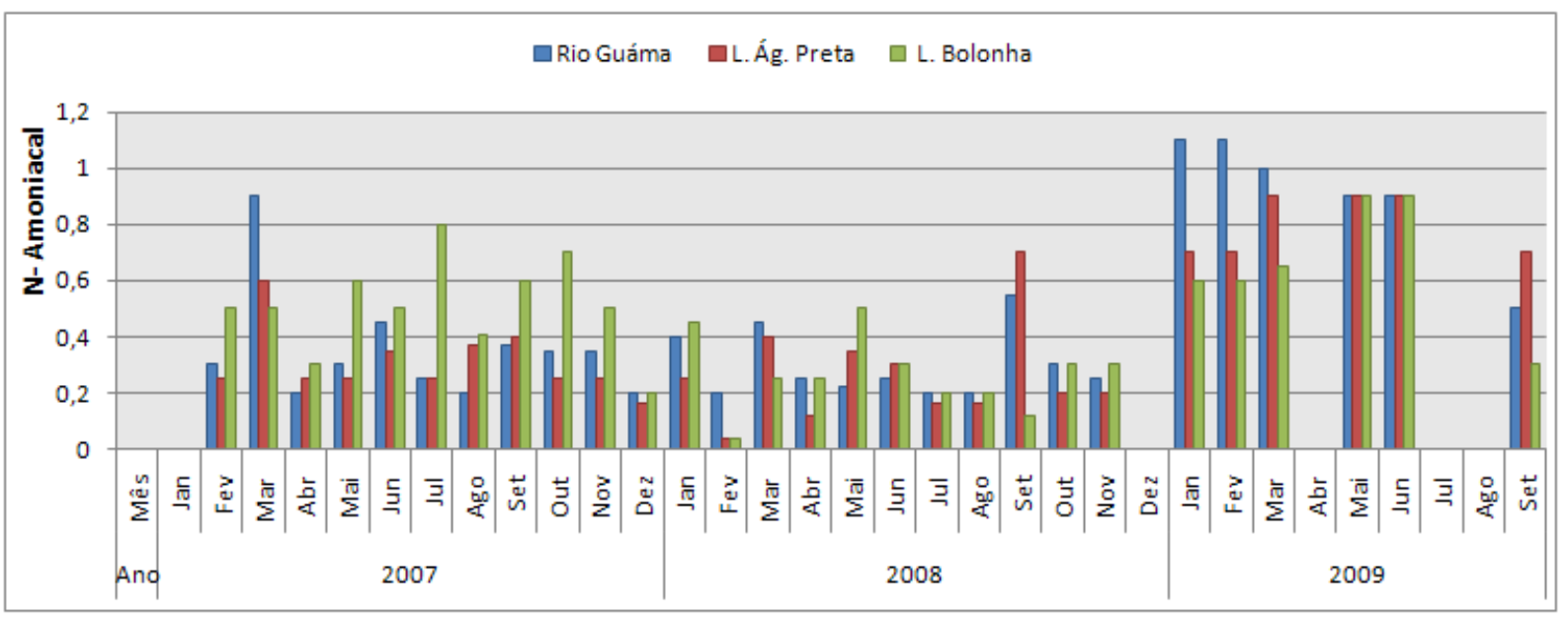

Figura 16. Perfil N-Amoniacal (mg/L).

Pela Figura 16, nota-se que os registros apontam valores maiores de $\mathrm{N}$-amoniacal em 2007 e 2008 para as águas do lago Bolonha. Nesse caso, a poluição recente está associada ao nitrogênio na forma de amônia causada pelo lançamento de esgotos das residências próximas ao Complexo onde se encontra o manancial e esgotos que chegam através dos tubos e desembocam dentro da APA nas proximidades do lago Bolonha.

\subsection{Cloretos}

O teor de cloretos é um indicador de poluição por esgotos domésticos nas águas, porém os valores registrados estão dentro dos limites exigidos pela resolução Conama 357/05512 que é de $250 \mathrm{mg} / \mathrm{L}$. O menor valor foi de $6 \mathrm{mg} / \mathrm{L}$ e o maior valor foi de $72 \mathrm{mg} / \mathrm{L}$.

Em novembro de 2007 e 2008, os valores fogem à normalidade em relação aos outros meses do ano, a ação antropogênica por meio de despejos domésticos altera a normalidade padrão dos valores de cloreto encontrados nas águas do manancial (Figura 17).

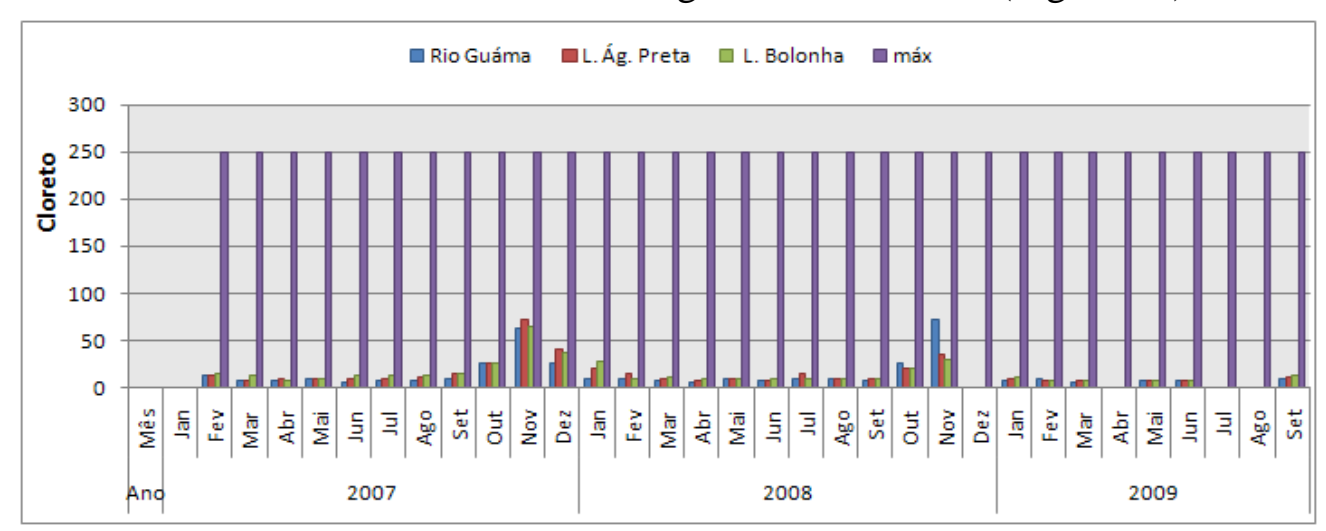

Figura 17. Perfil cloreto (mg/L). 
VASCONCELOS, V. de M. M.; SOUZA, C. F. Caracterização dos parâmetros de qualidade da água do manancial Utinga, Belém, PA, Brasil. Ambi-Agua, Taubaté, v. 6, n. 2, p. 305-324, 2011. (doi:10.4136/ambiagua.202)

\subsection{Alcalinidade}

Em janeiro/2007, dezembro/2008 e abril, agosto, setembro/2009 não foi realizado o monitoramento. Isso implica a avaliação da qualidade das águas do manancial.

A alcalinidade das águas ocorre na presença de bicarbonatos produzidos pela ação do gás carbônico dissolvido na água sobre rochas calcárias. A alcalinidade não tem significado sanitário, a menos que seja devido a hidróxidos ou que contribua na qualidade de sólidos totais (Figura 18).

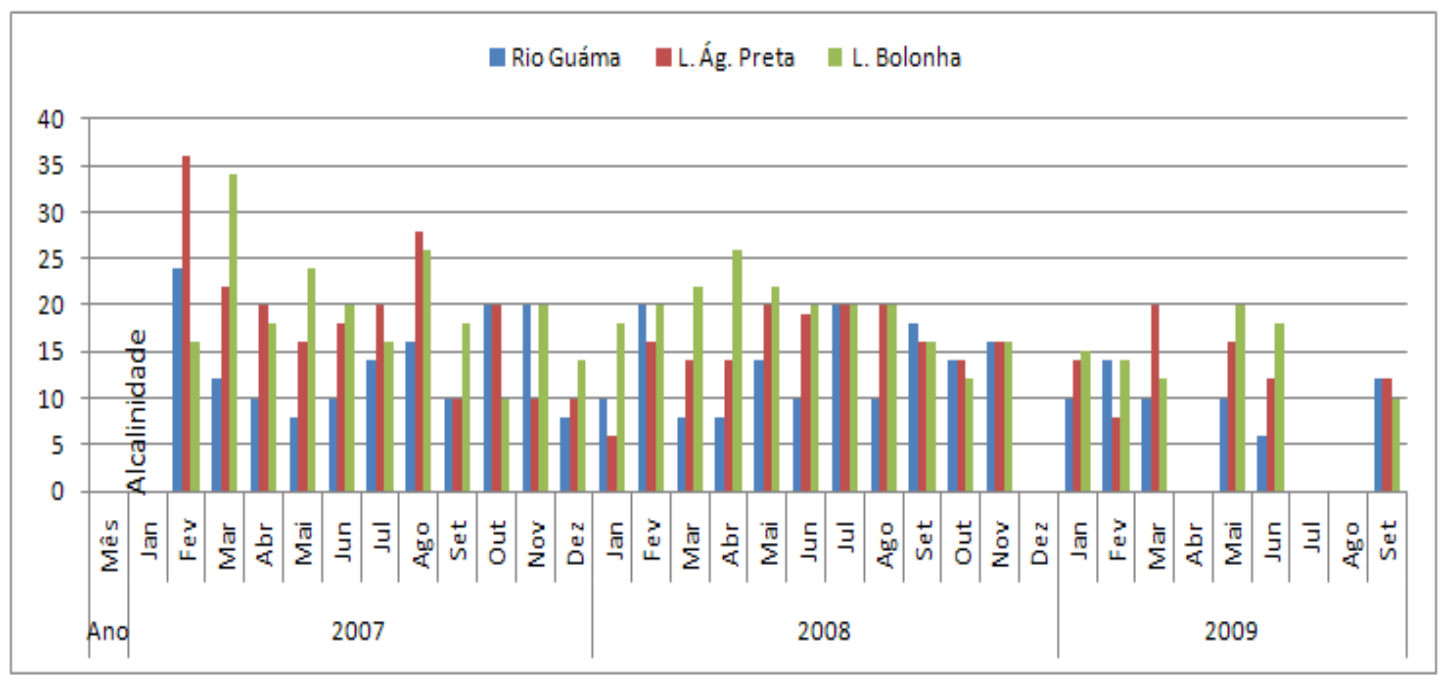

Figura 18. Perfil alcalinidade do Metil Orange (mg/L).

Entretanto os bicarbonatos de $\mathrm{Ca}$ e $\mathrm{Mg}$ também causam dureza temporária, além de liberar o $\mathrm{CO}_{2}$, quando submetidos ao calor nas caldeiras, essa substância dissolvido na água é altamente corrosiva. Para fins potáveis, a alcalinidade não deve exceder a $250 \mathrm{mg} / \mathrm{L}$.

Vale ressaltar que a ETA Bolonha funcionava até março de 2010 com uma sobrecarga de aproximadamente $1 \mathrm{~m}^{3} / \mathrm{s}$ e esse fato contribuía para a ineficiência do tratamento da água no local. No entanto, na primeira quinzena de março de 2010 foi inaugurada a nova estação com capacidade igual a da primeira, 3,36 m³ produção de tratamento. A sobrecarga foi repassada para nova estação que no momento opera apenas com $60 \%$ de sua capacidade.

\section{CONCLUSÃO}

Os valores da variável cor aparente foram influenciados diretamente pelas elevações da turbidez, que estão associadas à maior produção de lixos, esgotos e quantidades de poluição que são lançadas no corpo d'água ou levadas pelas chuvas até os lagos. Também o estudo mostrou que a cada ano que passa os valores das variáveis cor e turbidez estão aumentando nos meses de maior precipitação. A presença do nitrato e n-amoniacal está abaixo do nível máximo exigido pela resolução 357 CONAMA, porém, o lago Bolonha se encontra com aproximadamente 85\% da sua área em estado de eutrofização. Também o nível de oxigênio dissolvido apresentou valores maiores que o mínimo de $5 \mathrm{mg} / \mathrm{L}$. Portanto, todas as alterações verificadas vêm imprimindo modificações na qualidade da água do manancial do Utinga, gradativamente. 


\section{REFERÊNCIAS}

AMERICAN PUBLIC HEALTH ASSOCIATION - APHA. Standard methods for examination of water and wastewater. 20. ed. Washington, DC, 1998.

BRASIL. Conselho Nacional do Meio Ambiente - CONAMA. Resolução $\mathbf{n}^{\mathbf{0}}$ 357, de 17 de março de 2005. Dispõe sobre a classificação dos corpos de água e diretrizes ambientais para o seu enquadramento, bem como estabelece as condições e padrões de lançamento de efluentes, e dá outras providências. Disponível em: $<$ http://www.mma.gov.br/port/conama/res/res05/res35705.pdf $>$. Acesso em: 25 jul. 2011.

BRASIL. Ministério da Saúde. Portaria no 518, de 25 de março de 2004. Estabelece os procedimentos e responsabilidades relativos ao controle e vigilância da qualidade da água para consumo humano e seu padrão de potabilidade, e dá outras providências. Disponível em < http://www.agrolab.com.br/portaria\%20518_04.pdf>. Acesso em: 25 jul. 2011.

CARDOSO, T. M.; MONTEIRO, F. F.; VENTURIERI, A.; CAMPOS, G. S. Análises multitemporal da área de proteção ambiental de Belém. In: SIMPÓSIO BRASILEIRO DE SENSORIAMENTO REMOTO, 14., 25-30 abril 2009, Natal. Anais... São José dos Campos: INPE, 2009. p 1283-1290.

COMPANHIA DE HABITAÇÃO DO ESTADO DO PARÁ. 2003. Disponível em: <http://www.cohab.pa.gov.br/>. Acesso: 25 jul. 2011.

DI BERNARDO, L.; DI BERNARDO, A.; CENTURIONE FILHO, P. L. Ensaios de tratabilidade de água e dos resíduos gerados em estações de tratamento de água. São Carlos: RiMa, 2002.

ESTEVES, F. A. Fundamentos de limnoquímica. Rio de Janeiro: Interciência, 1988. 575p. http://dx.doi.org/10.1590/S1413-41522007000400006

FIGUEIRÊDO, M. C. B DE; TEIXEIRA, A. S.; ARAÚJO, L. DE F. P.; ROSA, M. F.; PAULINO, W. D.; MOTA, S. et al. Avaliação da vulnerabilidade ambiental de reservatórios à eutrofização. Eng. Sanit. Ambient., v. 12, n. 4, p. 399-409, out./dez. 2007. doi: 10.1590/S1413-41522007000400006.

GOOGLE EARTH. Lagos Bolonha e Água Preta. 2010. Disponível em : <http://www.google.com/earth/index.html>. Acesso em: 25 jul. 2011.

INSTITUTO NACIONAL DE METEOROLOGIA - INMET (Brasil). 2011. Disponível em: < http://www.inmet.gov.br>. Acesso em: 25 jul. 2011.

MATTA, M. A. S. Fundamentos hidrogeológicos para a gestão integrada dos recursos hídricos da região de Belém/Ananideua - Pará, Brasil. 2002. Tese (Doutorado em Geologia) - Centro de Geociências, Universidade Federal do Pará, Belém, 2002.

MOTA, S. Preservação de recursos hídricos. Rio de Janeiro: ABES, 1995.

NASCIMENTO, F. L. Proposta de biomonitoria no Reservatório Utinga - o sistema lacustre de abastecimento de água de Belém (Pará - Brasil). 2005. Monografia (Especialização em Gerenciamento Ambiental) - Universidade Federal do Pará, Belém, 2005. 
PARÁ. Governo Estadual. Plano Diretor de Mineração em Áreas Urbanas. Projeto de estudo do meio ambiente em sítios de extração de materiais de construção na região de Belém - Região metropolitana de Belém. Belém, 1995. 712p.

PARÁ. Secretaria de Estado de Ciências e Meio Ambiente. Lixo: este problema tem solução. Belém, 2005. 42p. (Saneamento Ambiental, 1)

PARÁ. Secretaria Executiva de Ciência, Tecnologia e Meio Ambiente. Núcleo de Hidrometeorologia. Precipitação pluviométrica: 2000 - 2005. Disponível em: $<$ http://www.para30graus.pa.gov.br/precipitacoes_mensal.htm>. Acesso: 25 jul. 2011.

RAMOS, J. P. Poluição e contaminação da orla de Belém-PA. In: UHLY, S.; SOUZA, E. L. (Org.). A questão da água na grande Belém. Belém: UFPS, 2004. 123p.

SANTOS, M. L. S.; PEREIRA, J. A. R.; RIBEIRO, L. S. C.; OLIVEIRA, M. M.; PEREIRA, J. A. R.; RIBEIRO, L. S. C. et al. Estudos preliminares das condições limnológicas no lago Água Preta (Belém/Pa). In: CONGRESSO BRASILEIRO DE LIMNOLOGIA, 10., 2005, Ilhéus. Resumos... Ilhéus: SBL, 2005. 1 CD-ROM.

SODRÉ, S. Do S. V. Hidroquímica dos Lagos Bolonha e Água Preta, mananciais de Belém - PA. 2007. Dissertação (Mestrado) - Universidade Federal do Pará, Belém, 2007.

TEIXEIRA, L. C . G. M . Análise de ciclo de vida aplicada ao gerenciamento de resíduos: o caso da ETA Bolonha - RMB. 2003. 340f. Tese (Doutorado em Desenvolvimento Sustentável do Trópico Úmido) - Núcleo de Altos Estudos Amazônicos, Universidade Federal do Pará, Belém, 2003.

TUNDISI, J. G.; MATSUMARA-TUNDISI, T. Eutrophication of lakes and reservoirs: acomparative analysis, case studies, perpectives. In: CORDEIRO-MARINO (ed.) Algae and environment: a general approach. São Paulo: Sociedade Brasileira de Ficologia, 1992. p. 1-33.

VON SPERLING, M. Introdução à qualidade das águas e ao tratamento de esgotos. 2. ed. Belo Horizonte: SEGRAC, 1996. 